CAPTAIN COOK 



\section{CAPTAIN COOK MASTER OF THE SEAS}

\section{FRANK MCLYNN}


Published with assistance from the Annie Burr Lewis Fund

Copyright (C) 2011 Frank McLynn

All rights reserved. This book may not be reproduced in whole or in part, in any form (beyond that copying permitted by Sections 107 and 108 of the U.S. Copyright Law and except by reviewers for the public press) without written permission from the publishers.

For information about this and other Yale University Press publications, please contact:

U.S. Office: sales.press@yale.edu www.yalebooks.com

Europe Office: sales@yaleup.co.uk www.yalebooks.co.uk

Set in Fournier MT by IDSUK (DataConnection) Ltd

Printed in Great Britain by TJ International Ltd, Padstow, Cornwall

Library of Congress Cataloging-in-Publication Data

McLynn, Frank.

Captain Cook/Frank McLynn.

p. cm.

ISBN 978-0-300-11421-8 (cl:alk. paper)

1. Cook, James, 1728-1779. 2. Explorers-Great Britain—Biography. 3. Voyages around the world - History-18th century. 4. Oceania—Discovery and exploration. I. Title.

G420.C65M35 2011

$910.92-\mathrm{dc} 22$

A catalogue record for this book is available from the British Library.

10987654321 
For Daniel and Ellen 
